\title{
Enhanced biogas production from landfill leachate by low frequency ultrasound
}

\author{
C. Can Yarimtepe \& N. Ayman Oz \\ Canakkale Onsekiz Mart University, Canakkale, Turkey
}

\begin{abstract}
Anaerobic treatment methods have been preferred for landfill leachate which has a high organic content. However, the wastewater is also characterized as a complex content and, therefore, stability problems can occur during the operation of anaerobic reactors due to the complex structure of the wastewater. The aim of this study is to investigate the integration of an ultrasound process for leachate as a pretreatment prior to anaerobic batch reactors to increase hydrolysis rate and biogas production. After $45 \mathrm{~min}$ sonication, the ratio of sCOD/tCOD was increased by $32 \%$ compared to raw leachate at $400 \mathrm{~W} / 1$. These results showed that ultrasonic pretreatment has a significant effect on converting particulate organic matter to soluble organic matters. During the anaerobic batch tests, biogas production and methane content are increased by $33 \%$ and $15 \%$ in pretreated leachate and the raw leachate, respectively. The increases can be attributed to the improvement on biodegradability of leachate and increase in sCOD concentrations by ultrasonic pretreatment. As a conclusion, the increase in COD solubilisation by sonication enhanced biogas production and methane yield in anaerobic batch tests in leachate samples.

Keywords: landfill leachate, anaerobic treatment, ultrasound, biogas, energy.
\end{abstract}

\section{Introduction}

Solid waste has become one of the most important environmental problems as a result of increased population and development of industry (Bolan et al. [1]) and its quantity and composition changes from country to country, even city to city due to local conditions, climate and consumption patterns (Buenrostro et al. [2]). In Turkey, typical municipal solid waste has about $50 \%$ of organic waste, $25 \%$ of recyclable waste materials and $25 \%$ of other waste (Metin et al. [3]). In 
developing countries, landfilling is still one of the most common ways to dispose of municipal solid waste. Although it is an economical, agreeable and commonly adopted method for solid waste management, it has nevertheless some environmental problems such as landfilll leachate, methane emissions, etc. (Christian and Armour [4]). Landfill leachate which contains inorganic salts, heavy metals, high amount of biodegradable organics, and refractory compounds such as humic substances, is one of the most complex wastewaters (Li et al. [5]). For landfill leachate treatment, physicochemical (Kang and Hwang [6]; Ramirez and de Velasquez [7]), biological (Ağdağ and Sponza [8]) and the combinations of these methods (Wei et al. [9]; Aziz et al. [10]) have been commonly proposed in the literature. Anaerobic treatment as a biological treatment methods have been extensively used for high strength wastewaters such as landfill leachate which have significant advantages such as low sludge production, less energy requirement and biogas production (Kennedy and Lentz [11]). However, anaerobic treatment also has some disadvantages especially in reactor stabilities. Therefore, combined processes which consist of a pretreatment method prior to anaerobic treatment have been proposed for leachate, in order to enhance the degradation of complex organic matters and to obtain high biogas generation with higher methane content (He et al. [12]). In recent years, ultrasound treatment has been recently used for the treatment of water (Hulsman et al. [13]), industrial wastewater (Matouq et al. [14]), sludge (Tiehm et al. [15]) and manure (Castrillón et al. [16]; Elbeshbishy et al. [17]) for different purposes such as pre or post treatment. Especially low frequency ultrasound process has been reported to be an effective pretreatment method to enhance anaerobic treatment in terms of both organic matter solubilization and biogas production (Lehne et al. [18]) by enhancing the hydrolysis step. It has been reported that especially low frequency ultrasonic pretreatment improves complex organic matter degradation by reducing particle size (Nickel and Neis [19]; Bougrier et al. [20]). Low frequency ultrasound treatment has been used for landfill leachate in limited studies (Wnag et al. [21]; Neczaj et al. [22]) and ultrasound pretreatment prior to anaerobic treatment have been examined only in two studies for landfill leachate (Oz and Yarimtepe [23]; Bohdziewicz et al. [24]), so far. In these studies, it has been reported that ultrasound pretreatment combined with anaerobic processes enhance organic matter degradation and improve both biogas production rate and methane yield of biogas in landfill leachate.

With the above aforementioned, the aim of this study is to investigate the effect of ultrasound pretreatment process prior to anaerobic batch reactors for landfill leachate as a pretreatment prior to anaerobic batch reactors to increase hydrolysis rate and biodegradation so improve the anaerobic treatment efficiencies in terms of biogas production.

\section{Material and method}

Landfill leachate has a variable composition due to the content of the solid waste and environmental conditions. The raw leachate which is used in this study, was collected from the leachate treatment system from Istanbul Environmental 
Management in Industry and Trade (ISTAC). ISTAÇ A.Ş stores 14,000 tons of domestic waste per day in landfill sites throughout Istanbul. In total, $3600 \mathrm{~m}^{3}$ landfill leachate is produced from this waste per day. Amount of leachate produced in Kemerburgaz/Odayeri landfill site is $2400 \mathrm{~m}^{3} /$ day whereas the amount of leachate produced in Şile/Kömürcüoda landfill site is $1200 \mathrm{~m}^{3} /$ day. Landfill leachate characterization is summarized in Table 1.

Table 1: Leachate characterization.

\begin{tabular}{|l|c|c|}
\hline Parameter & Unit & Value \\
\hline $\mathrm{pH}$ & - & 7.38 \\
\hline Turbidity & $\mathrm{NTU}$ & 1200 \\
\hline Total Suspended Solid & $\mathrm{mg} / \mathrm{l}$ & 2300 \\
\hline Total Chemical Oxygen Demand (tCOD) & $\mathrm{mg} / \mathrm{l}$ & 28500 \\
\hline Soluable Chemical Oxygen Demand (sCOD) & $\mathrm{mg} / \mathrm{l}$ & 13000 \\
\hline Biochemical Oxygen Demand (BOD) & $\mathrm{mg} / \mathrm{l}$ & 10025 \\
\hline Total Organic Carbon (TOC) & $\mathrm{mg} / 1$ & 7946 \\
\hline Total Nitrogen (TN) & $\mathrm{mg} / \mathrm{l}$ & 2641 \\
\hline Sulphate & $\mathrm{mg} / 1$ & 910 \\
\hline Conductivity & $\mu \mathrm{S} / \mathrm{cm}$ & 32,8 \\
\hline Total Phosphorus (TP) & $\mathrm{mg} / \mathrm{l}$ & 30.5 \\
\hline Nitrate & $\mathrm{mg} / \mathrm{l}$ & 12.5 \\
\hline
\end{tabular}

Seed sludge samples which is used in anaerobic tests, was taken from an anaerobic expanded granular sludge bed reactor (EGSB) of a beverage factory. The concentration of the total solid, total suspended solid, total volatile solid and total volatile suspended solid of the seed sludge were monitored and is shown in Table 2.

Table 2: Seed sludge characterization.

\begin{tabular}{|l|c|c|}
\hline Parameter & Unit & Value \\
\hline Total Solid Matter & $\mathrm{mg} / \mathrm{l}$ & 69675 \\
\hline Total Volatile Solid & $\mathrm{mg} / \mathrm{l}$ & 51425 \\
\hline Total Suspended Solid & $\mathrm{mg} / \mathrm{l}$ & 35020 \\
\hline Total Volatile Suspended Solid & $\mathrm{mg} / \mathrm{l}$ & 20450 \\
\hline
\end{tabular}

Activity of the seed sludge was determined by the Specific Methanogenic Activity (SMA) test. The SMA test unit consists of four reactors with active volume of $900 \mathrm{ml}$. A water bath was used for control the temperature $\left(35 \pm 2{ }^{\circ} \mathrm{C}\right)$ and mixing $(90 \mathrm{rpm})$. Biogas production during the SMA test was monitored with Milli Gas Counter (MGC) (Ritter, Germany). Biogas composition was 
measured by Agilent 7820A Gas Chromatography with a thermal conductivity detector (TCD) and a molecular sieve column (HP INNOWAX $30 \mathrm{~m}$ x $0.25 \mathrm{~mm}$ and $30 \mathrm{~m} \times 0.50 \mathrm{~mm})$. In SMA tests, four different acetate concentrations (10002000-3000 and $4000 \mathrm{mg} / \mathrm{l}$ ) was used and the potential methane production was calculated by the formula expressed in literature (Ince et al. [25]). According to SMA test, maximum specific methanogenic activity of the seed sludge was determined as $398 \mathrm{ml} \mathrm{CH}_{4} / \mathrm{g}$ TVS-day at optimum acetate concentration.

Complete experimental analyses were performed according to the Standard Methods (APHA [26]). Ultrasonic experimental setup was composed of a standard generator (Vibra Cell505, $500 \mathrm{~W}$ ) equipped with a metallic probe of $1.9 \mathrm{~cm}$ in diameter and a supplied power of about $400 \mathrm{~W} / 1$ at $20 \mathrm{kHz}$ (Figure 1).

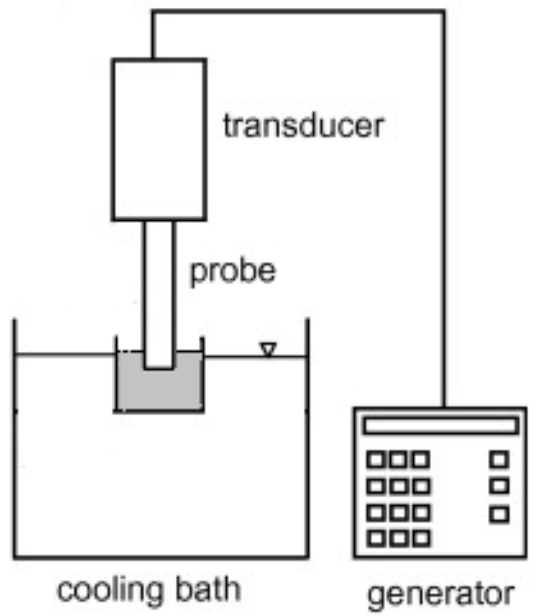

Figure 1: Ultrasonic experimental setup.

Ultrasonic treatment was applied in $250 \mathrm{ml}$ of dark glass bottles which were in a water cooling bath for temperature controlling. Leachate samples were sonicated for 2, 4, 6, 8, 10, 15, 30 and 45 minutes. At the end of the ultrasonic experiments, tCOD and sCOD were analysed with Hach Lange DR 5000 Spectrophotometer according to the Standard Methods (APHA [26]). After sonification process, changes in TCOD and SCOD were monitored to investigate the effect of ultrasound process on organic matter solubilization.

The anaerobic tests of landfill leachate were performed in glass reactors with $900 \mathrm{ml}$ active volume. Reactors were submerged in a water bath for temperature controlling and mixing. Raw and ultrasonically treated landfill leachate were added to reactors separately which contain seed sludge and mineral stock solution (Valcke and Verstraete [27]). In anaerobic reactors; F/M ratio were set to 0.5 and $\mathrm{pH}$ was set to 7 . During the anaerobic tests; sCOD removal efficiencies, biogas production and methane content were monitored. sCOD removal efficiencies were determined by spectrophotometer according to standard methods. Biogas production was measured with Ritter MilliGas 
Counter (Ritter, Bochum, Germany) and biogas composition especially methane content was determined with Agilent 7820A Gas Chromatography which is equipped with a thermal conductivity detector (TCD) and a molecular sieve column (HP INNOWAX $30 \mathrm{~m} \times 0.25 \mathrm{~mm}$ and $30 \mathrm{~m} \times 0.50 \mathrm{~mm}$ ).

\section{Result and discussion}

In this study, effects of ultrasound pretreatment on organic matter solubilization were investigated by $\mathrm{sCOD} / \mathrm{tCOD}$ ratio. Raw landfill leachate samples were sonicated for up to 45 minutes $(2,4,6,8,10,15,30$ and $45 \mathrm{~min})$ at $400 \mathrm{~W} / 1$. In low frequency sonication, while tCOD concentration was about stable $(28500 \pm 176 \mathrm{mg} / \mathrm{l}), \mathrm{sCOD}$ concentration increased therefore $\mathrm{sCOD} / \mathrm{tCOD}$ ratio was increased due to particulate organic matter turns to soluble forms by high cavitation energy. Table 3 shows changes in tCOD and sCOD concentration during the ultrasonic pretreatment.

Table 3: Changes in tCOD and sCOD concentration during the ultrasonic pretreatment.

\begin{tabular}{|c|c|c|c|}
\hline Ultrasound duration, min & $\mathrm{tCOD}, \mathrm{mg} / \mathrm{l}$ & $\mathrm{sCOD}, \mathrm{mg} / \mathrm{l}$ & $\mathrm{sCOD} / \mathrm{tCOD}$ \\
\hline 0 & \multirow{9}{*}{$28500 \pm 176$} & 13000 & 0.46 \\
\hline 2 & & 13730 & 0.49 \\
\hline 4 & & 14750 & 0.52 \\
\hline 6 & & 15050 & 0.53 \\
\hline 8 & & 15750 & 0.55 \\
\hline 10 & & 16100 & 0.57 \\
\hline 15 & & 16450 & 0.57 \\
\hline 30 & & 16470 & 0.59 \\
\hline 45 & & 17400 & 0.61 \\
\hline
\end{tabular}

After $45 \mathrm{~min}$ sonication, ratio of $\mathrm{sCOD} / \mathrm{tCOD}$ increase was reached the highest value which is $32 \%$ when compare with raw leachate. Figure 2 shows the increase in ratio of $\mathrm{sCOD} / \mathrm{tCOD}$ during low frequency ultrasound pretreatment.

These results showed that ultrasonic pretreatment have a significant effect on converting particulate organic matter to soluble organic matters. In literature; there are several studies which have investigated the increase of organic matter solubilisation by low frequency ultrasound for sludge and manure (Dewil et al. [28]; Elbeshbishy et al. [17]; Bougrier et al. [29] and Luste and Luostrarinen [30]). However, there are a few studies for wastewater (Sangave and Pandit [31], Gibson et al. [32] and $\mathrm{Oz}$ and Uzun [33]) and only two studies for landfill leachate $(\mathrm{Oz}$ and Yarimtepe [23]; Bohdziewicz et al. [24]), so far. In these studies; increase in solubilization has been reported as $35 \%$ at $600 \mathrm{~W} / 1$ for 45 min sonication. 


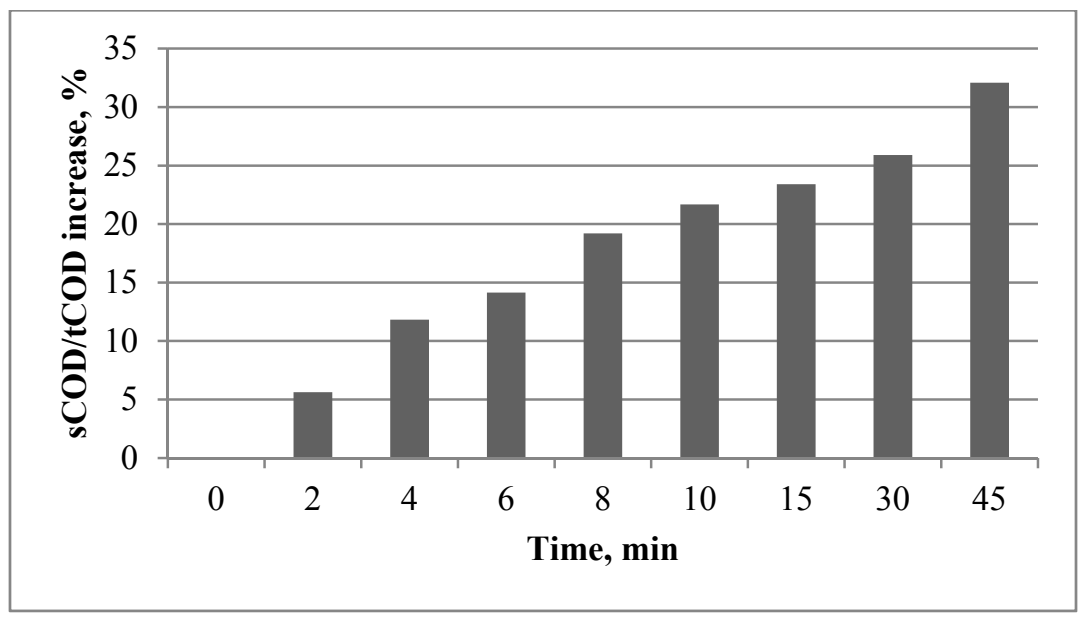

Figure 2: $\quad$ sCOD/tCOD increase during sonication.

After low frequency ultrasound pretreatment, anaerobic batch tests were performed with raw and pretreated landfill leachate samples for the purpose of explaining the positive effects of ultrasonic treatment prior to anaerobic treatment. After pretreatment by ultrasound, anaerobic batch tests were carried out at $\mathrm{F} / \mathrm{M}$ ratio of 0.5 for both pretreated landfill leachate and raw landfill leachate as a control reactor. In anaerobic batch test; sludge samples from an anaerobic expanded granular sludge bed reactor (EGSB) of a beverage factory which have maximum specific methanogenic activity as $398 \mathrm{ml} \mathrm{CH4/g} \mathrm{TVS-day}$ at optimum acetate concentration, were used as seed sludge. During the anaerobic batch tests; sCOD removal efficiencies, biogas production and composition were monitored. Figure 3 shows the sCOD removal efficiencies during the anaerobic batch test. As seen from figure, ultrasonication has a favorable effect on sCOD removal efficiencies. After 45 min sonication at 400 $\mathrm{W} / 1$, the sCOD removal efficiency of pretreated and raw leachate was $44 \%$ and $60 \%$ in anaerobic batch tests, respectively.

Biogas production which is one of the main advantage of anaerobic treatment, was also remarkably improved by low frequency ultrasonic pretreatment during anaerobic batch tests. Total biogas production and methane yield during anaerobic batch reactors is shown in Figure 4.

In anaerobic batch tests; biogas production was determined as 341 and $453 \mathrm{ml}$ while methane production of biogas were determined as 87 and $101 \mathrm{ml} \mathrm{CH4/gr}$ VS-day for raw and pretreated landfill leachate, respectively. Therefore, in batch reactor which carried out with ultrasound pretreated leachate, 33\% more biogas was obtained compared with control reactor which operated with raw leachate. During the experiments, methane content of the biogas were determined as $60 \%$ in raw landfill leachate and $69 \%$ in ultrasonically pretreated landfill leachate. Therefore, $15 \%$ increase in methane yield was obtained for ultrasonically pretreated landfill leachate. In literature, increase in methane yield has been 


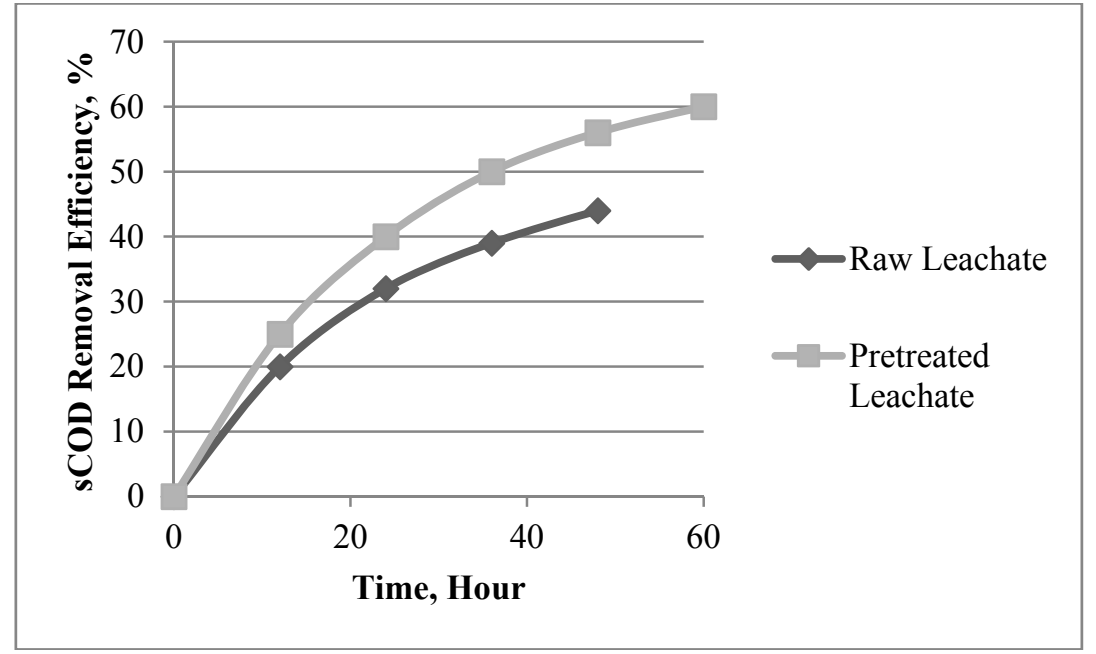

Figure 3: sCOD removal efficiencies during anaerobic batch test.

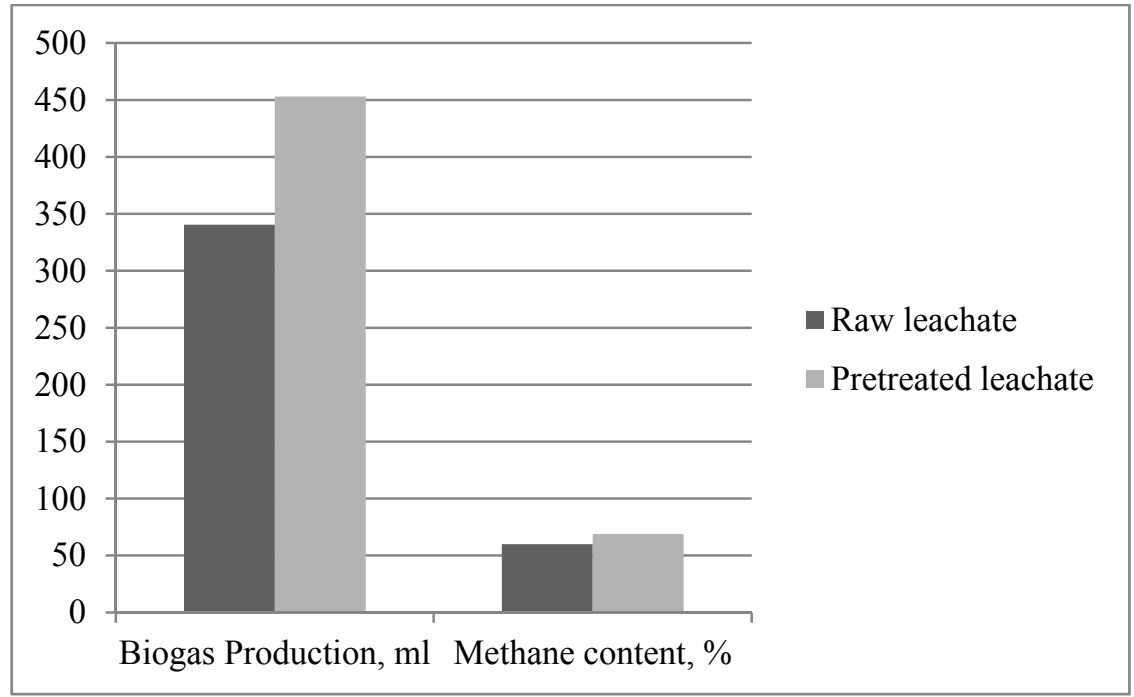

Figure 4: Total biogas production and methane content of raw and pretreated leachate.

reported between $18 \%$ and $22 \%$ for landfill leachate in various operational conditions.

Results obtained from this study showed that ultrasonic pretreatment has a positive effect on sCOD increase in pretreated landfill leachate samples and enhanced biogas production and methane yield in anaerobic batch reactors. 


\section{Conclusion}

In this study, ultrasonication has been investigated for landfill leachate which is a strong wastewater, as a pretreatment in order to enhance anaerobic treatability for landfill leachate. Low frequency ultrasound pretreatment was performed for raw landfill leachate prior to anaerobic batch tests. After ultrasound pretreatment; it has been detected a significant increase in SCOD concentrations. Therefore, this increase in COD solubilisation by sonication enhanced biogas production and methane yield in anaerobic batch tests in landfill leachate samples when compared with the control reactor. As a conclusion, overall results showed that the ultrasound pretreatment improves anaerobic treatability of landfill leachate. There is a potential in combination of low frequency ultrasound pretreatment prior to anaerobic processes for landfill leachate treatment in terms of better reactor performance and higher biogas production with higher methane yield. This combined method can be used for other complex wastewaters to enhance anaerobic treatability. With the enhancement in anaerobic treatability, it is considered that lower reaction times and smaller reactor volumes can also be achieved.

\section{References}

[1] Bolan, N.S., Thangarajan, R., Seshadri, B., Jena, U., Das, K. C., Wang, H., Naidu, R., Landfills as a biorefinery to produce biomass and capture biogas. Bioresource Technology, 135, pp. 578-587, 2013.

[2] Buenrostro, O., Bocco, G., Cram, S., Classification of sources of municipal solid wastes in developing countries. Resources, Conservation and Recycling, 32 (1), pp. 29-41, 2001.

[3] Metin, E., Eröztürk, A., Neyim, C., Solid waste management practices and review of recovery and recycling operations in Turkey. Waste Management, 23, pp. 425-432, 2003.

[4] Christian, U. O., Armour, A., Post-landfill siting perceptions of nearby residents: a case study of Halton landfill. Appl. Geogr., 20, pp. 137-154, 2000.

[5] Li, H., Zhou, S., Sun, Y., Feng, P., Li, J., Advanced treatment of landfill leachate by a new combination process in a full-scale plant. J. of Hazard. Mater., 172, pp. 408-415, 2009.

[6] Kang, Y., Hwang, K., Effects of reaction conditions on the oxidation efficiency in the Fenton process. Water Res., 34, pp. 2786-2790, 2000.

[7] Ramirez, I. M., Orta de Velasquez, M. T., Removal and transformation of recalcitrant organic matter from stabilized saline landfill leachates by coagulation-ozonation coupling processes. Water Res., 38, pp. 23592367, 2004.

[8] Ağdă̆, O. N., Sponza, D. T., Anaerobic/aerobic treatment of municipal landfill leachate in sequential two-stage up-flow anaerobic sludge blanket reactor (UASB)/completely stirred tank reactor (CSTR) systems. Process Biochem., 40, pp. 895-902, 2005. 
[9] Wei, Y., Ji, M., Li, R., Qin, F., Organic and nitrogen removal from landfill leachate in aerobic granular sludge sequencing batch reactors. Waste Manag., 32, pp. 448-455, 2012.

[10] Aziz, S. Q., Aziz, H. A., Yusoff, M. S., Bashir, M. J. K., Landfill leachate treatment using powdered activated carbon augmented sequencing batch reactor (SBR) process: Optimization by response surface methodology. $J$. Hazard. Mater., 189, pp. 404-413, 2011.

[11] Kennedy, K. J., Lentz, E. M., Treatment of landfill leachate using sequencing batch and continuous flow upflow anaerobic sludge blanket (UASB) reactors. Water Res., 34, pp. 3640-3656, 2010.

[12] He, P., Qu, X., Shao, L., Li, G., Lee, D., Leachate pretreatment for enhancing organic matter conversion in landfill bioreactor. J. Hazard. Mater., 142, pp. 288-296, 2007.

[13] Hulsman, A., Joris, K., Lambert, N., Rediers, H., Declerck, P., Delaedt, Y., Ollevier, F., Liers, S., Evaluation of process parameters of ultrasonic treatment of bacterial suspensions in a pilot scale water disinfection system. Ultrason. Sonochem., 17, pp. 1004-1009, 2010.

[14] Matouq, M. A., Al-Anber, Z. A., The application of high frequency ultrasound waves to remove ammonia from simulated industrial wastewater, Ultrason. Sonochem., 14, pp. 393-397, 2007.

[15] Tiehm, A., Nickel, K., Neis, U., The use of ultrasound to accelerate the anaerobic digestion of sewage sludge. Water Sci. and Technol., 36, pp. 121-128, 1997.

[16] Castrillón, L., Fernández-Nava, Y., Ormaechea, P., Marañón, E., Optimization of biogas production from cattle manure by pre-treatment with ultrasound and co-digestion with crude glycerine. Bioresour. Technol., 102, pp. 7845-7849, 2011.

[17] Elbeshbishy, E., Aldin, S., Hafez, H., Nakhla, G., Ray, M., Impact of ultrasonication of hog manure on anaerobic digestability. Ultrason. Sonochem., 18, pp. 164-171, 2011.

[18] Lehne, G., Müller, A., Schwedes, J., Mechanical disintegration of sewage sludge. Water Science \& Technology, 43, pp. 19-26, 2000.

[19] Nickel, K., Neis, U., Ultrasonic disintegration of biosolids for improved biodegradation. Ultrasonics Sonochemistry, 14, pp. 450-455, 2007.

[20] Bougrier, C., Carrère, H., Delgenès, J. P., Solubilisation of waste-activated sludge by ultrasonic treatment. Chem. Eng. J., 106, pp. 163-169, 2005.

[21] Wang, S., Wu, X., Wang, Y., Li, Q., Tao, M., Removal of organic matter and ammonia nitrogen from landfill leachate by ultrasound. Ultrason. Sonochem, 15, pp. 933-937, 2008.

[22] Neczaj, E., Kacprzak, M., Lach, J., Okoniewska, E., et al., Effect of sonication on combined treatment of landfill leachate and domestic sewage in SBR reactor. Desalination, 204, pp. 227-233, 2007.

[23] Oz, N. A. and Yarimtepe, C., Ultrasound assisted biogas production from landfill leachate. Waste Manag., 34, pp. 1165-1170, 2014. 
[24] Bohdziewicz, J., Kwarciak, A., Neczaj, E., Influence of ultrasound field on landfill leachate treatment by means of anaerobic process. Enviro. Protec. Engineering, 31, pp. 3-4, 2005.

[25] Ince, O., Kolukirik, M., Oz, N. A., Ince, B. K., Comparative evaluation of full-scale UASB reactors treating alcohol distillery wastewaters in terms of performance and methanogenic activity. Journal of Chemical Technology and Biotechnology, 80, pp. 138-144, 2005.

[26] APHA, AWWA, WPCF, Standard Methods for the Examination of Water and Wastewater. American Public Health Association, Washington, DC, 20th ed., 1998.

[27] Valcke, D., Verstraete, W., A Practical Method to Estimate the Acetoclastic Methanogenic Biomass in Anaerobic Reactors. Res. J. of the Water Pollut. Control Fed., 55, pp. 1191-1195, 1983.

[28] Dewil, R., Baeyens, J., Goutvrind, R., Ultrasonic treatment of waste activated sludge. Environ. Progress, 25/2, pp. 121-128, 2006.

[29] Bougrier, C., Albasi, C., Delgenès, J.P., Carrère, H., Effect of ultrasonic, thermal and ozone pre-treatments on waste activated sludge solubilisation and anaerobic biodegradability. Chem. Eng. and Process.: Process Intensif., 45, pp. 711-718, 2006.

[30] Luste, S., Luostrarinen, S., Enhanced methane production from ultrasound pre-treated and hygienized dairy cattle slurry. Waste Manag., 31, pp. 2174-2179, 2011.

[31] Sangave, P., Pandit, A. B., Enhancement in biodegradability of distillery wastewater using enzymatic pretreatment. J. of Environ. Manag., 78, pp. 77-85, 2006.

[32] Gibson, J., Hon, H., Farnood, R., Droppo, I. G., Seto, P., Effects of ultrasound on suspended particles in municipal wastewater. Water Res., 43, pp. 2251-2259, 2009.

[33] Oz, N.A and Uzun, A.C., Ultrasound pretreatment for enhanced biogas production from olive mill wastewater. Ultrasonic Sonochem., 22, pp. 565-572, 2015. 